\title{
Knowledge-Based Entrepreneurship and Globalization: Correlates for the Wealth of Nations and Perspectives from Nigeria
}

\author{
Paul T. Akuhwa1, Cephas A. Gbande², Benedict S. Akorga'3 ${ }^{3}$ Zachariah S. Adye 4 \\ ${ }^{1}$ OTIJOSH Resources Limited, Abuja, Nigeria \\ ${ }^{2}$ Faculty of Administration, Department of Business Administration, Nassarawa State University, Keffi, Nigeria \\ ${ }^{3}$ Cornerstone Insurance PLC, Abuja, Nigeria \\ ${ }^{4}$ Office of the Secretary of the Government of Benue State, Makurdi, Nigeria \\ Email: akuhwa.paul@gmail.com, Cgbande3@gmail.com, benakorga@gmail.com, zachadye@gmail.com
}

Received 27 June 2015; accepted 18 August 2015; published 21 August 2015

Copyright (C) 2015 by authors and Scientific Research Publishing Inc.

This work is licensed under the Creative Commons Attribution International License (CC BY). http://creativecommons.org/licenses/by/4.0/

(c) (i) Open Access

\section{Abstract}

Though Knowledge based entrepreneurship (KBE) is yet an evolving concept and globalization is without an acceptable concept globally, their tenets represent sound methods and strategies for socioeconomic development. Inextricably, KBE and globalization phenomena could be seen as mutually exclusive and collectively exhaustive in exploiting socioeconomic development capital. In this paper, the authors investigated and found out that the defining role of both KBE and globalization was to relate as correlates for the wealth of nations, and also was in an invaluable relationship. KBE is defined as variables that engender innovation, creativity, entrepreneurial culture and orientation with science and technology to underpin optima value creation. These include measurable inputs such as micro, small and medium enterprises (MSME) performance and literacy rates at a given time period in the economy. Globalization on the other hand is a multifaceted, multidisciplinary and complex phenomenon that is proxy on economic, political and social globalization indexes, and internet penetration at a given time period in the same economy. This paper tested two hypotheses to prove the construct that KBE and globalization were correlates for wealth of nations with very significant results using secondary data. Research triangulation was also performed to pragmatically prove the results using primary data. Both meta-analyses were conducted using IBM SPSS 21 software on the main model, the multiple regression, a confirmatory model and the chi-square. Finally, the paper called for policy for improving training and education of science and technology content to the entrepreneurs, while taking a 360 degrees approach to promote and intensify globalization practices in Nigeria, and by extension, to other global economies.

\section{Keywords}

Entrepreneurship Process, Knowledge Management, Globalization, Innovation and Creativity, 


\section{Education and Learning}

\section{Introduction}

\subsection{The Role of KBE and Globalization in the Economy}

The importance of knowledge-based entrepreneurship (KBE) and globalization has attracted many seminal researchers and scholar-practitioners globally. However, there is no catholic concept of KBE and globalization among the theorists as these phenomena are continuously undergoing paradigmatic evolutions. But their varying conceptual approaches possess common meaning on thematic and terminological grounds. The root of KBE is the entrepreneur, that factor of production, which possesses varying dictions seen from different theoretic according to ideological bases of the theorists. Globalization still remains the most controversial, but generally viewed from three major varying ideological bases due to its complexity: the realists, the liberals, and the Marxists. But functionally, globalization is the most challenging phenomenon in human civilization history, a force of change, and a law of competitive advantage and competitive collaboration.

Knowledge-based entrepreneurship (KBE) is a very important socio-economic phenomenon that drives innovation, economic growth and development [1]. KBE is an effective mechanism for the transformation of knowledge into innovation and new economic activities. The issue of knowledge-based entrepreneurship is becoming more and more important in both advanced western countries, advancing south and for the new member states [2]. Other theorists posit that KBE refers to the transmission of knowledge which has been generated within the fields of science and technology in anticipation of commercial application. In particular, the emphasis of $\mathrm{KBE}$ is on the development of new technologies and the introduction of new products, processes and the actors: new firms, universities and sources of external finance [2]. KBE usually carries some commercial business potential with new production technologies and products that drive the process of economic growth and allow innovation rents to be appropriated. In recent years, some questions have attracted increasing interest both in economic research and in politics [3]. The questions are: how does new knowledge from scientific research find its way into the commercial part of the innovation system? And, how does it support technological advancement? Landstrom believes that entrepreneurship is the process of innovation in economic organizations which either introduces new products or diversifies markets [4].

The great need for knowledge-based entrepreneurs in our society for obvious invaluable reasons that altogether accrues the wealth of any nation's economy remains [2] [5]. First, KBEs stimulate the knowledge diffusion from research to business. Second, KBEs revitalize industry by filling gaps and by capturing technology-driven business opportunities. Third, KBEs are important drivers in the continuous adaptation of industry and businesses to the ever-changing conditions on national and global markets. Fourth, some of the KBEs succeed in creating stunning ventures that surpasses the community of well established, well run companies on valuation and shareholder value to underline the importance of a vibrant community of start-ups as the breeding ground for future large and globally competitive companies. Fifth, KBEs impact positively on the gross domestic product (GDP) visibly, and whether big or small, growing or stationary, they provide exciting and challenging working lives for founders and employees [5]. In a robust knowledge-based entrepreneurship envisioned, access to resources enabling and exploitation of new technological knowledge are really inevitable [3].

In the climes of globalization, however, the Millennium Report succinctly declares that "the greatest challenge faced today is to ensure that globalization becomes a positive force for all the world's people, ... Inclusive globalization must be built on the great enabling force of the market, but market forces alone will not achieve it. It requires a broader effort to create a shared future, based upon our common humanity in all its diversity" [6]. Though, globalization is a controversial term; the phenomenon underpinned by the force of change is an irreversible process in accord with natural laws [7] [8]. It means a lot to different people with no catholic concept, but cutting across all facets and disciplines in the general human ecology. This explains the position of Adesina on the goal of globalization, succinctly positioning that:

"Globalization has been used rather loosely to stand for a variety of things: the shrinking of the world into a global village, the awesome changes brought about or mandated by the revolution in information technology, the collapse of boundaries between different worlds, expanding connectivity of all forms of interaction. 
Globalization facilitates the removal of barriers among nations of the world, thereby giving social relations unhindered access. Its unique characteristics often includes increased capital mobility, decline in costs of transportation, computing and communications. Other aims of globalization from the economic perspective include: (a) internationalization of production accompanied by changes in the structure of production, (b) expansion of international trade and services, and (c) widening and deepening of international capital flows. All these imply a more connected world. In essence, globalization has a major aim of diffusion of cultures, commerce and communication among countries of the world in order to bring about homogenization. Globalization reveals the interconnectedness within and across regions of the world due to the growing social, economic, political networks, education, information, and communications technology of different groups of people. It reveals the extent to which the actions of one group of humans exert either positive or negative impact on others" [8].

More so, globalization has created the dearth of distance as new communication technologies have triggered a virtual spatial revolution in terms of the geography of production [9]. Perhaps, globalization increased due to a push factor, a shift in the comparative advantage of high-wage countries towards knowledge-based economic activity [10]. Two decades ago, conventional wisdom predicted that globalization would render the demise of the region. The obsession of policymakers around the globe to create "the next Silicon Valley" reveals the increased importance of geographic proximity and regional agglomerations as well as of the role of SMEs and entrepreneurial activity [10]. Globalization is built on great enabling force of the market and a broader effort to create a shared future based upon common humanity in all its diversity. However, the greatest challenge faced today is to ensure that globalization becomes a positive force for the world premising on more trade, more markets, more business, more information, more jobs, and more opportunities [6].

\subsection{The Foundation of Knowledge Based Entrepreneurship (KBE) and Globalization}

Entrepreneurs are important to us: they create jobs, they innovate, they challenge the existing industry and business community, and their activities even impact the gross domestic product of nations [5]. Google in 2006 said "entrepreneurship" was the process of looking at things in such a way that possible solution to problems and perceived needs may evolve in venturing. This is indicating that "entrepreneurship" is about creating business out of problems. Hence, an entrepreneur is an opportunity-driven person, seeking value-creating solutions to needs and problems and turns them into money and positive cash flow [5]. Now, can entrepreneurship be taught and learned? Peter F. Drucker said "what we need is an entrepreneurial society in which innovation and entrepreneurship are normal, steady and continual" [11]. The philosophy of entrepreneurship must be considered as life-long learning positioned by the late $18^{\text {th }}$ century education seminal theorist, John Dewey. Peter F. Drucker, further opined that, "most of what you hear about entrepreneurship is all wrong. It's not magic; it's not mysterious; and it has nothing to do with genes. It's a discipline and, like any discipline, it can be learned" [11]. In view of this, Dirk Meyer succinctly commentated:

"Education is the clearest path to individual opportunity and societal growth, and entrepreneurship education is especially vital to fuelling a more robust global economy. Entrepreneurs bring new ideas to life through innovation, creativity and the desire to build something of lasting value. Therefore, we must continually foster educational cultures within our companies, governments and communities to keep the entrepreneurship pipeline filled for generations to come” [12].

The Global Entrepreneurship Monitor (GEM) further reiterated that, while education is one of the most important foundations for economic development, entrepreneurship is a major driver of innovation and economic growth. "Entrepreneurship education plays an essential role in shaping attitudes, skills and culture...We believe entrepreneurial skills, attitudes and behaviours can be learned, and that exposure to entrepreneurship education throughout an individual's lifelong learning path, starting from youth and continuing through adulthood into higher education, as well as reaching out to those economically or socially excluded, is imperative” [12]. Thus, it is the quality of education and learning, and their mutual inclusiveness with entrepreneurship for commercial value creation that makes knowledge-based entrepreneurship (KBE). Knowledge based entrepreneurship, confronts the peculiarities of scientific knowledge that is epitomized by tacit and encoded knowledge, and scientifically, trained labour is required for transferring both forms of knowledge [3]. Furthermore, other studies posits 
that "entrepreneurship is a power house of innovation; it links with the commercialization of research results and technological innovations" [13]. These three concepts are essential for the creation and maintenance of wealth, even at a national level and additionally insinuates that entrepreneurs play important roles in the economy; increase of employment and commercialization of high-quality innovations. In view of this, “... accumulated tacit knowledge and culture of the entrepreneur are the resources essential to create wealth from research commercialization leading to technological innovation...” taking a technology view of KBE, it is some kind of "Technology-based entrepreneurship that is a reflection and a small component of the general entrepreneurship” [14]. $\mathrm{KBE}$ is also regarded as a regional and industrial based entrepreneurship; it improves creation of entrepreneurs in the regions by improving and sustaining the regional intellectual capabilities; resulting in increase of spin-offs and better utilization of new innovations [13].

The tenet of globalization is the driving force of technological, economic, social and political advancements aiding global integration and global network ecosystems through technological revolution. While there are many different aspects to the technological revolution, the advent of the microprocessor combined with its application in telecommunications have altered the economic meanings of national borders and distance making the world very much smaller and more integrated planet [9]. Globalization is affecting global economic development [15]. The concept of economic development refers to the process of improvement in the economic opportunities, and quality of human lives; and reduction in the poverty. Better health facilities, better education, clean environment and better utilization of resources are the important components of economic development. Moreover the justified distribution of goods and services is also the part of economic development. A good distribution network that includes the good transportation system results in not only better delivery of goods and services but the improvement of labors mobility [15].

Education is undergoing constant changes under the effects of globalisation. The effects of globalisation on education bring rapid developments in technology and communications and foreseeing changes within school systems across the world as ideas, values and knowledge, changing the roles of students and teachers, and producing a shift in society from industrialisation towards an information-based society [16]. Globalization reflects the effect on culture and brings about a new form of culture creating rapid socioeconomic developments. The rise of a global society, driven by technology and communication developments are shaping children, the future citizens of the world into "global citizens", intelligent people with a broad range of skills and knowledge to apply to a competitive, information based society [16]. The future of countries often lies within their ability to compete in a global market where industrial based economies are giving way to knowledge based industries, realising the importance of "knowledge, skills and the intellectual capacity to meet the challenges of accelerated change and uncertainty”. Education has become a lifelong learning and training process, developing transferable skills and knowledge that can be applied to competitive markets where knowledge and information is being traded as a commodity [16].

This paper would deduce from the foregoing that knowledge based entrepreneurship (KBE) and globalization are power twain and a couple in any economy. Poverty eradication, flexibility and competitiveness, access to existing and new market, technology diffusion and transfer, trade rate explosions with improved balance of payments (BOT) and balance of trade (BOT) accounting, information and communication technology (ICT) diffusion and advancements, improved education and learning among other quality outcomes are many benefits of KBE and globalization respectively. Additionally, other benefits such as improved business opportunities, improved business processes, improved manufacturing, and lowering of labor and products unit costs, improved pace for innovation and creativity, and improved network economics for global interconnectedness and competitive collaborations are the respective rents of KBE and globalization. The common ground of KBE and globalization posited by this paper is improved gross domestic product (GDP), a measure of the wealth of nations; they are by no means mutually exclusive but altogether complimentary.

Finally, this inquiry explores the relationships existing within the KBE and globalization landscapes. It also traced whether and/or how both correlates together, and whether they could together be exploited to enhance the wealth of nations with Nigeria as a case study. As a result, the paper is written in five sections with the foregoing introduction, the inquiry's problem, questions, and objectives in section one; and considered also two stated hypotheses that the paper scientifically tested. Section two discussed the literature of theoretical/or conceptual underpinning of thematic issues. Section three handled the methodology for data harvesting and model specification, while section four analyzed data and model for congruence and fit with results discussions. Section five closed the study with conclusion, recommendations and policy issues. 


\subsection{The Problem Statement}

GEM estimated that 388 million salient entrepreneurs worldwide were actively engaged in starting and running new businesses in 2011 [17]. Entrepreneurship requires command over suitable resources and in knowledgebased entrepreneurship; resources enabling access to and exploitation of new technological knowledge is inevitable. The requisite knowledge resources have to be attracted, coordinated and be integrated with the organization's expertise and capabilities to yield coherent business conception [3]. Therefore, an essential part of KBE is the organization of the knowledge transfer to commercial production and marketing activities promoting economic progress (contribution to GDP). Usually, the contribution to the GDP stems from creation of jobs, development of skilled and semi-skilled workers, and developing and adapting appropriate technological approaches among others [18]-[20].

The force of globalization has already brought considerable wealth to areas of the world long accustomed to only poverty, and even more wealth to areas that were doing quite well already by improving balance of tradeBOT and balance of payment-BOP accounting, improved mobility of labor and technology transfer. For example, the East-Asian and South-East Asian countries have turned to export-based economies to propel themselves up the development ladder. In the coastal regions of China, global market-oriented businesses have helped raise living standards for millions of people. This whirlwind of economic activity has brought many benefits and wealth for many people of the world [6]. Faster economic growth, higher living standards, accelerated innovation, and new opportunities for both individuals and countries are seen. Trans-national private capital flows have increased in the past two decades. For instance, total net capital flows to developing countries increased from an average of 120 billion USD of 2006 in the period of 1995-2000 to nearly 200 billion USD in 2007 [10]. Also, volume of goods, services and investments are transferring across the national borders very rapidly. On a daily basis approximately 1.5 billion USD foreign exchange transactions are taking place. Statistics shows that approximately 8.9 trillion USD of goods are transacted across borders and 2.1 trillion USD of services are provided across the borders presenting more and more opportunities as capital to accentuation of KBE and globalization. Research records of UNDP and World Bank in 2013 shows: United States ranks $5^{\text {th }}$ with a HDI of 0.914, GDP of 16, 768, 100 (millions of USD) and GI of 74.94; Ireland ranks $11^{\text {th }}$ with a HDI of 0.899, GDP of 234,077 (millions of USD) and GI of 92.17; Japan ranks $17^{\text {th }}$ with a HDI of 0.89 , GDP of 4,919,563 (millions of USD) and a GI of 65; whilst Nigeria, on the other hand ranks $152^{\text {nd }}$ with HDI of 0.504, GDP of 521,803 (millions of USD). More so, an estimated 25 million Americans were starting or running new businesses, and 7.7 million projected they would employ six or more people in the next five years. In addition to these entrepreneurs, an estimated 14 million Americans were running established business, of which 3.2 million projected employing six or more employees in the next five years [21]. In the OECD, GEM research shows that entrepreneurial activity in Ireland increased significantly in 2013 in contrast to the trends noted in the previous three years. For the first time in four years the more positive trends are more significant than the less positive trends. It also indicated approximately 32,000 individuals started a new business in 2013, men and women have substantially increased the rate at which they are starting new businesses, and 13\% of new business owners expect to have more than $75 \%$ of their customers outside Ireland [22]. These economies have deployed KBE and globalization to create and improve wealth for their nations through improved standard of living measured by human development index (HDI) and gross domestic product (GDP).

Nigeria, the case study of this paper has recently recorded a gross domestic product (GDP) value 522.64 billion US dollars in 2013 [23]. This GDP figure represents 0.84 per cent of the world making Nigeria’s economy the largest in Africa and the $26^{\text {th }}$ in the world [24]. This astounding economic growth does not indicate corresponding transformations (i.e. growth without development). Instead, the poverty level indicates that over 70 per cent of population is living below poverty line [23]. Severe environmental concerns; such as high dynamic unemployment, loss of values, crime, insurgencies, terrorism (Boko Haram group), youth restiveness and the directionless and clueless business society and groups. Also, actively present in Nigeria strongly are; the unsustainable healthcare system, non-investment supportive housing and transportation with severely inadequate energy supply, and etc. A global cross-section of economies transformation statistics shown afore indicated the economies of USA, OECD, Canada and Japan ranking highest, Asia economies such as Malaysia, Korea, and India are having moderate ranking. African economies especially Nigeria with moderate GDP is ranking very low in transformation indicators. Furthermore, the database of entrepreneurship shows that about 17,284,671 micros, small and medium enterprises (MSMEs) in Nigeria representing very low ratio of $11.5 \%$ of Nigerian population involved in MSME [25]. In other words, about “one-in-ten” of Nigerians are actively involved in 
MSME business for over three decades that cannot be compared with one-in-five American adult daily involvement in MSME businesses [17]. Though KBE and globalization are among the common denominators for socioeconomic activities, MSMEs globally are the custodian of KBEs. These represent the knowledge gap that this inquiry attempted to fill by answering these basic questions as the problem of the study: are KBE and globalization phenomena really creating wealth for nations? Why has there been wide economic disparity between the west, south and emerging economies in terms of wealth in spite embracing KBE and globalization? Can Nigeria benefit in this KBE and globalization game to create wealth?

\subsection{Research Questions}

The answers to these research questions solve the problems of the inquiry with this central question; how would $\mathrm{KBE}$ and globalization correlate to create or improve the wealth of nations? Other minor or sub-questions to answer by this paper are as follows:

1) Can KBE and globalization improve and create respectively the wealth of nations?

2) Are KBE and globalization really correlates?

3) How would Nigeria adopt and adapt the tenets of KBE and globalization?

\subsection{Hypothesis Statements}

This paper formulated hypotheses to be tested in order to confirm or prove theory underlying the propositions. The "positive" economist, Milton Friedman, posted that "a theory, or a hypothesis, that is not verifiable by appeal to empirical evidence may not be admissible, as a part of scientific enquiry" [26]. A statistical relationship, however strong and however suggestive, can never establish connections: our ideas about causation must come from outside statistics, ultimately from some theory or other... The point is that a statistical relationship in itself cannot logically imply causation. To apply causality, one must appeal to a priori or theoretical consideration [26]. The theoretical expectations or prior empirical work or both can be relied upon to formulate hypotheses. However, in the words of Stephen M. Stigler, "beware of testing too many hypotheses; the more you torture the data, the more likely they are to confess, but confession obtained under duress may not be admissible in the court of scientific opinion" [26]. But no matter how the hypotheses are formed, it is extremely important that the researcher establish these hypotheses before carrying out the empirical investigation. Otherwise the researcher would be guilty of circular reasoning or self-fulfilling prophesies [26]. Thus the two hypotheses this paper investigated are:

$\mathrm{H}_{01}$ : KBE and globalization does not create the wealth of nations.

$\mathrm{H}_{02}$ : KBE and globalization are not correlates for wealth creation.

\subsection{The Objective of the Paper}

The overarching objective of this paper is to exploit the socioeconomic benefits that underlie the KBE and globalization phenomena. These benefits would not only improve the HDI and GDP of economies through cloning socioeconomic development congruencies, but also, bridge the socioeconomic divide gaps globally. Other objectives to serve by this paper include:

1) To explore the capital that underlies KBE and globalization phenomena for wealth creation in Nigeria.

2) To develop a policy framework for adopting and adapting the KBE and globalization phenomena for value optimization in Nigeria.

3) To make an original contribution to the body of knowledge in KBE and globalization fields of study.

\section{Theoretical or Conceptual Framework and Literature Review}

\subsection{Conceptual Framework}

The absence of acceptable theory on globalization, and difficulty of a theory on knowledge based entrepreneurship (KBE) is a theoretical challenge of this study [7] [8] [27]. This requires seminal researchers, theorists and scholar-practitioners to do more work about a theory on KBE and globalization. As a result, their concept in this paper is based on conceptual positions of theorists on KBE and globalization. Thus, a conceptual framework is developed with variables representing themes that define both KBE and globalization, because a conceptual framework is the operationalization of a theory. Aconcept is an image or diagrammatic (or symbolic) represen- 
tation of an abstract view or idea; it is a complex mental formulation of experience [28]. A conceptual framework outlines possible courses of action and presents the best-fit approach to the idea by first identifying the research variables, pointing out the dependent and intervening variables, and shows the direction of the study [29]. It may be an adaptation of a model used in a previous study, with modifications to suit the inquiry. Thus, the conceptual framework of this study is a combination of two theoretical models (KBE and globalization) to give birth to the third (wealth of nations). The illustration of the framework is as shown below in Figure 1.

The framework in Figure 1 shows the variable components that are determinants of KBE; such as education, entrepreneurship development, innovation and creativity, science and technology acquisition and advancement for new product development, and commercial valuing of products and services etc. The determinant of a robust globalization is technology that underscores and propels economic, social and political aspects of globalization respectively. The plus (+) sign is for exclusive addition as a symbol of complementarity as opposed to mutual exclusiveness. It is often regulated by literacy level in a given economy that is still a function of education and experiential learning. The arrow $(\rightarrow)$ sign is moderated by ambidextrous enabling policy environment and process value chain improvements to enhance wealth maximization by optimizing these wealth creation criteria: knowledge diffusion, revitalizing industries, market adaptation, global competitiveness, and employment etc.

\subsection{Theoretical Review of Concepts}

\subsubsection{Knowledge Based Entrepreneurship (KBE)}

As earlier posited, KBE has no catholic theory. Though many seminal researchers conceptualize it from different constructs, but the common grounds of their concepts remains that there is first an entrepreneur, who traditionally and otherwise is a factor of production in the economy [30] [31]. The entrepreneur, through education and learning acquires innovation and creativity, science and technology has control of resources and becomes a knowledge based entrepreneur (KBE). The KBE in the final analysis turns these resources (real, potential and acquired) into products and services of commercial value [1] [2] [12]. Thus, KBE refers to the transmis-

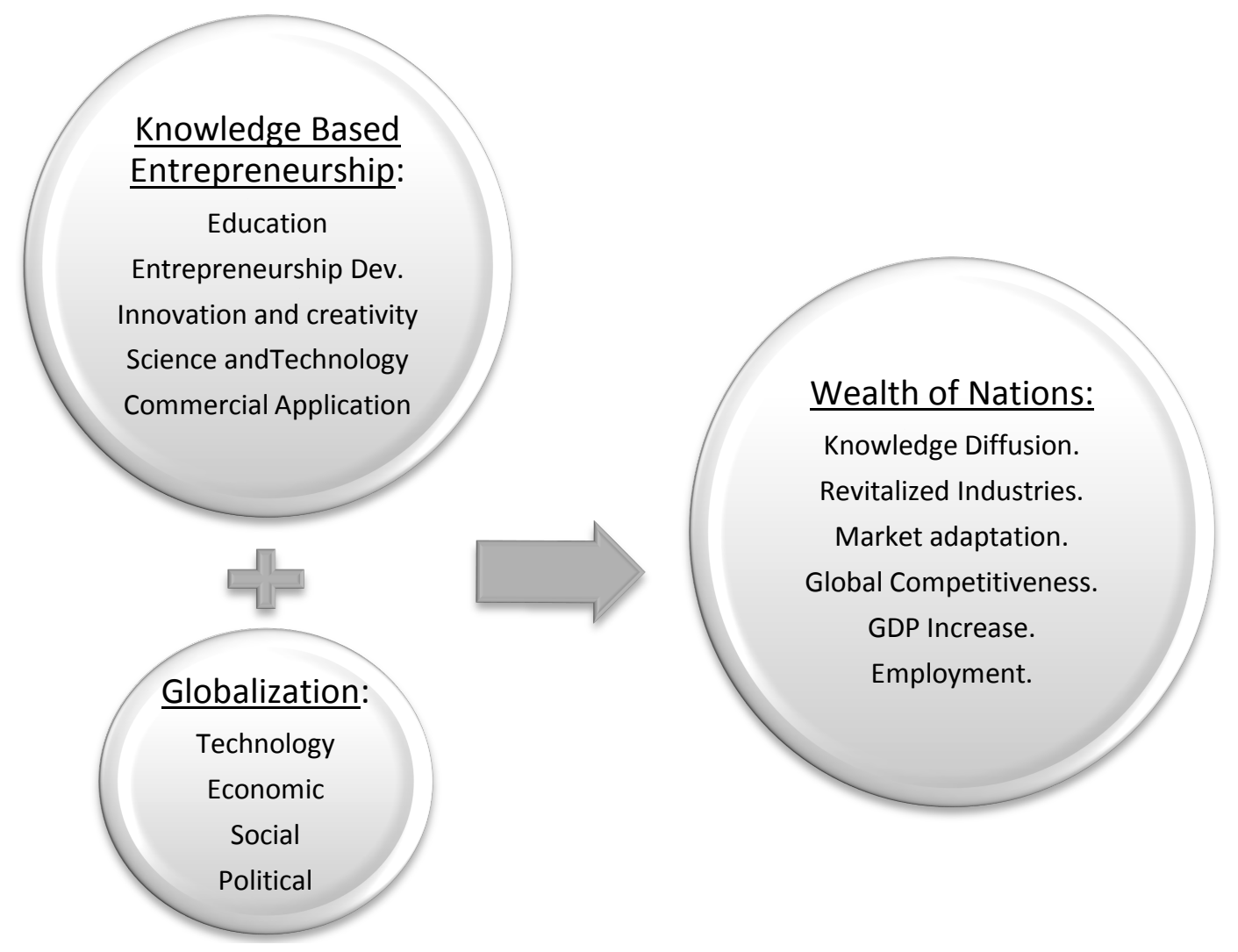

Figure 1. Conceptual framework of wealth creation from KBE and globalization. 
sion of knowledge that has been generated within the fields of science, technology and otherwise in anticipation of commercial application. In particular the emphasis is on the development of new technologies and the introduction of new products and processes, and the actors, such as; new firms, universities and sources of external finance [2]. Concomitantly, knowledge-based entrepreneurship (KBE) is a very important socio-economic phenomenon that drives innovation, economic growth and development. This kind of entrepreneurship is characterized by high potential for technology upgrading. Moreover, KBE is an effective mechanism for the transformation of knowledge into innovation and new economic activities [1].

Specifically, Kanellos holds similar conceptual view with many scholars that a better term for "knowledge based entrepreneurship" would be "Innovative Entrepreneurship" because this type of entrepreneurship involves the development and diffusion of product innovations or process innovations. He succinctly opines that, any form of entrepreneurship is based on exploitation of some knowledge, from basic to advanced types of knowledge, even when it comes to arbitrage opportunities [1]. Therefore, this study conceptualizes knowledge based entrepreneurship as a phenomenon driven mainly by climes of information-knowledge philosophy which is characterized by high value innovation and creativity, deploying technology, information and communication technology (ICT) epistemologies for product and services giving commercial or market value. KBE also relates to the activities which the role of innovation and creating new knowledge is central to optimum value creation [1] [32] [33].

\subsubsection{Entrepreneurship Development (ED)}

Entrepreneurship development (ED) is the main variable of KBE; and involves all efforts tailored toward making the entrepreneur (factor of production) enhanced in the economy. This process requires someone to be first identified as an entrepreneur. The entrepreneur then undergoes transformation through education and experiential training, imbuement of entrepreneurship culture and business management acumen to possess entrepreneurship orientation, and to become mentally and psychologically equipped for the entrepreneurial market and commercial value creation; the landscape of KBE. Change is a paradigm shift, hence entrepreneurship presents a phenomenon of a paradigm globally [34]. Robert Carton in his study on global entrepreneurship paradigm was succinct that, globally, there are two primary dimensions of the entrepreneurship paradigm as it pertains to society. These paradigms, which he defined as a shifts caused by the dynamism nature and heterogeneous interactions of environmental factors are: new venture formation and new venture performance. New venture formation deals with the antecedents to the formation of a new venture and its creation. Thus, new ventures have accounted for substantially all of the new job creation in the global economy in recent years [17] [20] [30] [31] [35]. Accordingly, it is in the public interest to understand those factors that are essential to fostering new venture formation, be able to identify those individuals that have the skills to seek out and recognize opportunities in the environment and that have the propensity to act. Thus, understanding the behaviours necessary for new venture formation is essential [34].

The second element of the paradigm, new venture performance includes the development and implementation of new venture strategy, the nature of the external environment munificence and industry structure, the accumulation of resources, building of an organization including developing distinctive competences, establishing strategic networks, capturing customers, and establishing an organization culture and values. Robert Carton further opined that, while entrepreneurial activity growth is not a sufficient condition to remain in the entrepreneurship paradigm, it is inherent in reaching self-sustainability. When a firm or company reaches self-sustainability, it exits the entrepreneurship paradigm. At that time, the organization is generally not dependent upon the founding team, risk has been reduced, sustainable competitive advantage(s) have been created, the rate of change has drastically reduced, and repetition in the functions of the organization has occurred. The venture must have also achieved financial success sufficient to fund on-going growth [34]. Therefore, this study deduces that both new start-ups and existing (established) ventures exist in either or both of the paradigms that bear invaluable implications on KBE philosophy.

\subsubsection{Entrepreneurship Education and Innovation}

Research shows that the success of a company and entrepreneurship ventures in the 21st century will be determined by the extent to which it creates and utilises knowledge, which is considered to be the most important source of a firm's sustainable competitive advantage [36]. The entrepreneurs utilize markets to exchange goods and services, thereby, ordering maximization of profit while driving increased innovation and productivity in the 
economy [37]. Business research has long identified innovation as one of the entrepreneurs defining characteristics. In this view, writing in the mid-1900s of a famed scholar Joseph Schumpeter commented, "entrepreneurial innovation is the essence of capitalism.” Further, a contemporary economist, Milton Friedman argued that free markets, competition, and consumer choices are also essential components of capitalism [37], whilst capitalism remains the best and most competitive production economy. Other, research also shows that innovation and education are power twain of any business venture as education is the bedrock of entrepreneurship which in turn is the bedrock of wealth creation [38] [39]. Accordingly, education en-houses and grooms knowledge is through structured and unstructured learning for continuous growth (through knowledge management process) of this knowledge. Knowledge management is the deliberate and systematic coordination of an organisation's people, processes, technology, and organisational structure in order to create more value through innovation [40]. Knowledge is a function of the quality of education acquired through learning, both in planned (structured) and experiential (unstructured) forms. It is both an individual attribute and a collective attribute of the venture organization. Knowledge is tacit and explicit in nature. The knowledge residing in the entrepreneur that has not been documented is tacit, whereas knowledge that has been documented is explicit knowledge [18] [32] [40] [41]. Generally, knowledge has four major attributes that made it invaluable for KBE: it is a firm's asset, it has different forms, it has a location, and it is situational [32]. Knowledge leads to wisdom that the KBE requires to run any venture. Wisdom is thought of to be the collective and individual experience of applying knowledge to the solution of problems. Wisdom involves the where, when, and how to apply knowledge [3]. Therefore, this paper generalizes that, KBE through knowledge subverts heterogeneous environmental problems deploying know-where, know-when and know-how and their combinations for innovation and creativity, to initiate market positions and market changes for commercial value creation.

Entrepreneurship and organizations are bio-corporate and exists in an ecological setting, creating and gathering knowledge using a variety of methods and mechanisms. Through data gathering to process information of customers, markets, products and stakeholders; careful information and corresponding measurement are made of planned activities. Through trial and error (i.e. experimentation) and feedback from stakeholders and environment in general, experience (wisdom) is gained. The KBE, through this entrepreneurial learning, learns and adjusts behaviours to reflect that learning by making effective decisions in creating new business processes and changing environmental patterns. The value chain of KBE knowledge management involves four stages: knowledge acquisition, knowledge storage, knowledge dissemination and knowledge application [32]. These value chain variables are fathomed and moderated by education. However, knowledge that is not shared and applied to the practical problem facing the market, economy and entrepreneurs does not create nor add any commercial value; but becomes a waste. One of the primary roles of KBE is to use education for effective knowledge application for commercial value creation avoiding knowledge wastages. Thus, the KBE with new knowledge formation clones new practices, new products and services, and new markets. This is the height of innovation and creativity. In this view, KBE are managers that focus on developing people to adapt to new technologies and extraordinary environmental shifts, to achieve high performance and total venture effectiveness.

Finally, current trends are by no means exhausted and that makes society all the more complex. And if society becomes more complex, then the business environment of the average entrepreneur also becomes more complex. The entrepreneur must deal with these developments and will have to make better and smarter use of technological, organisational and marketing competencies in order to stay ahead of all these complexities. An important means to reduce these complexities is using knowledge [41]. Knowledge is the factor with which entrepreneurs, by transforming into the KBE phenomenon, can distinguish themselves from their competitors. Apart from this, knowledge is the means with which the poorly organised business environment can become well organised, and with which the complex world becomes manageable and with which unclear items can be interpreted [41]. Success depends far more on someone's ability to maintain control of a complex situation, someone's ability to weed out the essential from the non-essential and someone's capacity for strategic thinking combined with energetic tactical execution, a continuous focus on serving customers' needs while maintaining a sense of urgency. These abilities do not unfold unless you keep an overview of that entrepreneurship venture through learning, and this is again is preconditioned by someone's ability to think in entireties and interrelations and to grasp a complex and highly detailed entrepreneurial projects [5].

\subsubsection{Globalization}

Globalization phenomenon is complex because the main accounts of world politics all see globalization differ- 
ently; some treat it as a temporary phase in human history, others see it as the latest manifestation of the growth of western capitalism and modernization; and others see it as representing a fundamental transformation of the world politics, one that requires new ways of understanding [7]. This complex nature of globalization leads to three different opposing schools, but the important thing is that, it is not just that the world has changed but that the changes are qualitative and not merely quantitative. In fact, each school sees globalization differently as discussed below [7]:

1) For the realist, globalization does not alter the world significantly, such as the territorial division of the world into nation-states. The increased interconnectedness between economies and societies only makes for more dependence on one another, the same cannot be said about states-system. States still remain sovereignty, and globalization does not render obsolete the struggle for political powers between the states. It does not also undermine the importance of the threat of the use of force, or the importance of the balance of power. Globalization, then, may affect economic, social, and cultural lives, but does not transcend the international political system of states.

2) For the liberals, they tend to see globalization as the end of long-running transformation of the world politics. According to them, the states are no longer as central actors as they once were. In the place of states a myriad of actors of different importance according to the issue area concerned. Liberals are concerned particularly with the revolution in technology and communications represented by globalization. This economically and technologically increased interconnectedness between societies result in a different pattern of the world political relations from that which has gone before. States are no longer sealed units, if ever they were, and as a result the world looks like a cobweb of relations.

3) For the Marxists, globalization is a bit of sham. There is really nothing new but the latest stage in the development of international capitalism. It does not mark a qualitative shift in world politics, and nor does it render all our existing theories and concepts redundant. Above all it is a western-led phenomenon which basically simply furthers the development of international capitalism. Rather than make the world alike, it further deepens the existing divide between the core, semi-periphery, and the periphery.

On the whole, these schools represent the rightists and leftists positions about globalization phenomenon. The rightists' supports globalization, whilst the leftists oppose it because the rightists' looks at the "soft side" while the leftists takes to only the "hard side" of globalization. This paper considers globalization from the "soft side" that is clime to its capability to increase and create the wealth of nations. Therefore in this conceptual lens, 'globalization' is "that on-going trend whereby the world in many respect and at a generally accelerating rate become one relatively borderless sphere. Territorial spaces remain significant, to be sure, but the geography of the world politics is now no longer reducible to territoriality" [7]. This concept covers all variables aspects, but specifically, this paper is concerned with the socio-economic, political, and technological variables of globalization. The socio-economic variables defining internationalization increases transactions among states as reflected in the flows of trade, investments, and capital. It facilitates and shapes inter-state agreements on trade, investments, and capital, as well as domestic policies permitting the private sector (which KBE remains the foundation) to transact abroad [7]. The political variable on the other hand describes government policies which reduce the role of states in the economy such as dismantling of trade tariffs and barriers, the deregulation and opening of the financial sector to foreign investors, and the privatization of state owned enterprises. Lastly, the technological variable refers to the revolution in modern communication, made possible by technological advances making distance and location less important factors but equally in the calculations of other actors such as firm's investment decisions, and other activities [7]. By and large, the reality of globalization is summed up in these outstanding rent yields:

1) The pace of increased economic transformation.

2) Information and communication technology (ICT) revolution.

3) Creation of a global culture.

4) Increased homogeneity of the world.

5) The death of time and space.

6) Emerging global polity.

7) Development of a cosmopolitan culture which people 'think globally and act locally.

8) Transfer of risky cultures (AIDS, pollution, terrorism and etc.).

Finally, the globalization phenomenon as earlier mentioned is underpinned by the force of change, and is an irreversible process in accord with natural laws [7] [8]. It means a lot to different people with no catholic con- 
cept, but cutting across all facets and disciplines in the general human ecology with lots of socio-economic, technological, and political benefits to the whole world; the object of this paper.

\subsection{KBE and Globalization as Correlates}

Microsoft Encarta dictionary defines "correlate" as a "transitive and intransitive verb meaning to have or show mutual relationship. This implies having a mutual or complementary relationship, or showing that two or more things such as a cause and an effect have mutual or complementary relationship." In this view, this inquiry investigates in order to find out whether KBE and globalization are correlates as the two phenomena carries the capacity for increasing and creating the wealth of nations. More so, some studies shows that there are many factors that determine growth, and globalization (measured by trade) empirically as well as entrepreneurship, and both having a positive impact on economic growth [42]. Georgiou used panel data of Western World and Japan from 1999 to 2006 using a least square regression model estimated by the Eview software package, and found out that; the model empirically showed a low $\mathrm{R}^{2}$ value indicating that entrepreneurship and globalization are not the only measures of economic growth. However, the results showed a strong impact of entrepreneurship and globalization on economic growth (the wealth of nations). In another study, Shahabadi and Etemad investigated globalization and its economic effect on entrepreneurship. Their study was delimited to vocational schools in Fars province as one of most famous provinces at the centre of Iran [27]. They used questionnaire and 5 point Likert scale. Additionally, they used multi-stage random sampling which is one method of probability techniques and selected 10 vocational schools. Using some measures of central tendency such as mean and percentage in order to analyse the results of the survey; they found out that, economic effects of globalization on entrepreneurship would require ambidextrous attention to vocational courses, technology and the use of information technology (IT). Also, in the process of globalization and in order to train experts for the economy of capitalization, many of the educational affairs are to be led by entrepreneurs in the direction of vocational courses. Their study finally concluded that globalization does not have limits to the economic effects on entrepreneurship, depicting a close relationship between entrepreneurship and globalization [27].

Furthermore, education is the bedrock of KBE that in turn is the bedrock of socio-economic growth and it is the core of entrepreneurship education all over the world. Collaborating this view, Othman, Othman and Ismail studied the "impact of globalization on entrepreneurship education and entrepreneurial skills in Higher Education Institutions" [43]. The study was interested in the increasing trend of changes and demand for entrepreneurship education due to the impact of globalization. Also, it aimed at observing the impact of globalization towards the demand for business and entrepreneurship education, as well as developing the entrepreneurial skills in Malaysia. The methodology of their study was descriptive statistics with sample number of 306 administrators from the higher education Institutions and data were obtained from questionnaires, which were then analysed. Their findings showed that there is an increasing demand for entrepreneurship education and entrepreneurial skills, which indicates that globalization has impacted towards the increasing demand for entrepreneurship education and entrepreneurial skills (the basic foundation of KBE). Lastly, the study found out that; an increasingly globalized and challenging world has resulted into demand for more competitive and creative graduates [44]. To support this view, online education, a product of globalization of education driven by the wheels of information and communication technology (ICT) has been in practice globally in the last two decades. Accordingly, many universities have reported an increase in the use of online tools for all inclusive educational learning and development worldwide. Over the past decades countless efforts have sought to integrate emerging Internet technologies into the teaching and learning process in higher education [44]. In the United States alone, online learning alternatives are proliferating rapidly. Recent estimates suggest that 1.5 million elementary and secondary students participated in some form of online learning in 2010 [45]. In Nigeria, however, online education started developing its roots in 2004 when the National Open University of Nigeria (NOUN) commenced. But a teaming population of students in Nigeria have enrolled and are enrolling in online education in Europe, America and Asia on daily basis. Thus, this paper generalizes that educational, entrepreneurship, innovation and creativity studies with other relevant technology-based courses are studied online world wide. Also, through internet sources, e-libraries, GEM articles and a myriad of other scholarly journals and databases are open to learning on all subjects worldwide. These are the strong pointers for full emancipation of knowledge, innovation and creativity cultures for KBE and globalization.

Another research posited the phenomenon of KBE to be linked to the first three key aspects of entrepreneur- 
ship. First is the process of creation, that is, the process of creating something new that has value for both the entrepreneur and for the consumers. Second is the time and effort required to create something functionally new. Finally, the third important aspect of entrepreneurship that stands out from the above definition is to assess the risks involved in the process of creating a business venture [1]. Accordingly, KBE is considered to be linked to:

1) New firms.

2) Innovative firms.

3) Firms which have a significant knowledge-intensive in their activities.

4) Firms that exploit innovative opportunities not only in high-technology sectors but in diverse sectors.

$\mathrm{KBE}$ is therefore not only related to new firms (start-ups), but it is also referring to new and innovative firms with high knowledge intensity in their activities involved in a process of transforming knowledge into innovation. These firms transform knowledge into new or significantly improved goods and services that may enter in market. They are also companies that exploit innovative opportunities in various sectors and achieve, through their strategy, a sustainable competitive advantage [1]. The activity sectors of KBEs are not limited only to high-technology sectors but also in traditional industries and sectors that are either existing or new. Their business models depend on the knowledge required to exploit innovation opportunities and the creation of value and growth at the enterprise level. Therefore, the definition of KBE connects firms with knowledge economics, as a mechanism that turns knowledge into innovation. So, innovation can happen in any sector no matter how "traditional” it may be [1]. Lastly, KBE in this regime of knowledge economy and globalization would also clone business models from network-based strategies [32]. The importance of network-based strategies remains the possibility of large firms (keystone firms) developing alliances with smaller ones (MSMEs) through technology in the business ecosystem. In this business ecosystem, the smaller firms provides the innovation and creativity, whilst the larger firms in turn provides robust international distribution and marketing strategy of a magnitude that normally an MSME would have difficulty achieving [46]. Strategic alliances through network-based strategies create linkages globally between KBEs and global positioned keystone firms, the transnational corporations (TNCs) and other global firms. This becomes the hallmark of correlation sinew for wealth creation in the KBEs and globalization equation that is the object of this paper.

\section{Methodology and Model Specification}

\subsection{Methodology}

This article used quantitative mixed-model because of the need for triangulation and to satisfy the theory of pragmatism in research. Started by American philosophers, Charles Sanders Peirce and John Dewey, the philosophy of pragmatism says that researchers should use the approach or mixture of approaches that works the best in a real world situation. In short, what works is what is useful and should be used, regardless of any philosophical assumptions, paradigmatic assumptions, or any other type of assumptions [47]. Triangulation is conceived as the conduct of parallel (or otherwise duplicated) studies using different methods and/or models to achieve the same purpose, with a view to providing corroborating evidence for the conclusions drawn. As a technique of validation, it is drawn from the concept of triangulation in surveying. Alternative methods (or models) may also "tap different domains of knowing," to encourage or allow expression of different facets of knowledge or experience [48]. Thus, the mixed-model considered in this paper is multiple regression model (MRM) and chi square model (CSM). While the MRM considered secondary data for analysis, the CSM used primary data for validation and confirmation of results.

Furthermore, data gathering for the MRM is secondary source data from Central Bank of Nigeria (CBN) for loans remissions to MSMEs, and gross domestic product (GDP) statistics figures. Other secondary data is from National Bureau for Statistics (NBS) for literacy rate in Nigeria. The secondary data for globalization penetration and Information Technology (ICT) penetration in Nigeria are from World Economic Forum (WEF) and International Telecommunication Union (ITU) respectively. The secondary data collected being a time series data, a meta-analysis using a MRM for inferential statistical hypotheses testing is preferred. The MRM is clearly stated in equation 1 with all variables defined. The secondary data covered a time period from 2000-2013. The primary data elicits behaviours of executive and managers of MSME entrepreneurship firms and other firm's executives from other corporations with respect to KBE and globalization practices. The primary data was scored and collected through structured questionnaires. The questionnaire was constructed in a 10 point scoring format and ranked: rank A-Highest scores (8 - 10), rank B-Moderate scores (4 - 7), rank C-Low scores (1 - 3), 
and rank D-Zero score (0). This is a bivariate frequency or contingency table [49]. The CSM model is also clearly stated with all variables defined in Equation (2). This questionnaire was administered to 320 respondents grouped into MSMEs, corporation's executives/managers, and others (mostly lecturers/instructors, and their students). 300 of the questionnaires were returned while 20 were not. The IBM SPSS 21 software was used to perform the meta-analyses both for the MRM and CSM for results.

\subsection{Model Specification}

The two generic models used for the meta-analysis to test hypotheses $\mathrm{H}_{01}$ and $\mathrm{H}_{02}$ are the MRM and CSM; and for all of the models, the level of confidence is $95 \%$ with a chance probability or level of significance at $P(0.05)$. This is because, the regression is a technique that makes inference from a sample to a population, whilst the chisquare test evaluates the level of statistical significance attained by a bivariate relationship in the cross-tabulation. The chi-square procedure assumes that there is no relationship between the two variables in the population and determines whether any apparent relationship obtained in a sample cross-tabulation is attributable to chance [50].

\subsubsection{The Multiple Regression Model (MRM)}

The general MRM model for this work is;

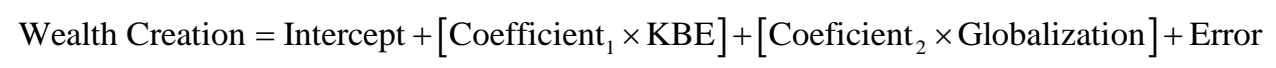

KBE and globalization have several predictors and each with a separate coefficient that defines the prediction relationship. The predictors of KBE are the Medium Scale, Small Scale and Micro Scale Enterprises Nigeria, and literacy rates (Lit.rate). From the secondary data collected, Small and Medium Scale Enterprises (SME) were categorized in one group, whilst Micro Scale Enterprises (ME) have different categorization. Thus, the KBE section becomes [SME + MSE + Lit.rate]. Also, Globalization have predicators such as openness to the world defined as economic, political and social aspects of globalization and Internet penetration (Int.P) measured by their penetration indexes respectively (i.e. GloIE, GloIP and GloIS). Thus, the Globalization section becomes [GloIE + GloIP + GloIS + Int.P]. So, each predictor variable has its own coefficient, and the outcome variable is predicted from the combination of all the variables multiplied by their respective coefficient plus a residual term [51]. Therefore, the MRM used in this paper for meta-analysis is:

$$
W=\beta_{o}+\beta_{1} X_{1}+\beta_{2} X_{2}+\beta_{3} X_{3}+\beta_{4} X_{4}+\beta_{5} X_{5}+\beta_{6} X_{6}+\beta_{7} X_{7}+\epsilon .
$$

where, $W$ is the wealth that is created by KBE and Globalization in an economy. Wealth creation is a measure of GDP as the total nominal output in a given year expressed as a percentage weight of the total GDP values obtained at a given time period. The KBE tradition here is taken as a proxy of the combination of $\operatorname{MSME}\left(X_{1}, X_{2}\right)$ and Literacy rate $\left(X_{3}\right)$. While, Globalization tradition is taken as a proxy of the combination of respective economic, political and social aspects $\left(X_{4}, X_{5}, X_{6}\right)$, and the internet penetration index $\left(X_{7}\right)$ aids the globalization. These variables are defined as below.

$X_{1}=$ Commercial Banks Loans to Small and Medium Enterprises from 2000 to 2013.

$X_{2}=$ Microfinance Banks Loans and Advances to Micro-enterprises from 2000 to 2013.

$X_{3}=$ Literacy rate measured as a percentage weight of the total population having obtained basic or elementary education as a foundation for KBE and globalization from 2000 to 2013.

$X_{4}=$ Economic Globalization Index measured as a weight of increasing economic interdependence of national economies across the world through a rapid increase in cross-border movement of goods, service, technology and capital that propels globalization from 2000 to 2013.

$X_{5}=$ Political Globalization Index measured as a weight of reducing the importance of nation states and extending national functions to facilitate international agreement, and to influence public policy across national boundaries, propelling globalization from 2000 to 2013.

$X_{6}=$ Social Globalization Index measured as a weight of the transmission of ideas, meanings and values around the world in such a way as to extend and intensify social relations, marked by the common consumption of cultures that have been diffused by the Internet, popular culture media, and international travel.total population exposure to internet, ICT friendliness and global integration that propels globalization from 2000 to 2013.

$X_{7}=$ Internet penetration index measured as a weight of total population exposure to internet, and ICT friendliness that propels KBE and globalization from 2000 to 2013. 
$\beta_{1}, \beta_{2}, \cdots, \beta_{7}=$ coefficient of the regression or the regression constant and measures the marginal propensity of SMEs, MEs and literacy rate growths, and globalization and internet penetration measures as a rate of change or the slope of the regression line. They also measure their combination for knowledge based entrepreneurship and globalization effects in wealth creation.

$\epsilon=$ The disturbance, or error term, it is a random (stochastic) variables that has well defined the probabilistic properties. The disturbance term may represent those factors that affect economic performance but are not taken into account explicitly. In other words it is unexplained variable that may be affecting wealth creation that may not be possible to measure or omitted during measurement.

Finally, this model is statistical or functional because the outcome (in this case, wealth of nations measured by the GDP) is a function of KBE and globalization, and the decision parameters to be extracted from the model are Pearson correlation $(r)$, coefficient of multiple determination $\left(R^{2}\right)$, coefficient of multiple correlation $(R),(t)$ and $(F)$ statistics and $\beta$ values. For decision issues, if the values of $t$ and $F$ calculated from the sample data exceeds the appropriate minimum (critical) values taking into account the degrees of freedom (df) and a statistical level of significance (in this case, $\alpha=0.05$ ); the null hypothesis is rejected, otherwise it is accepted [49]-[53]. Also, if the beta values $(\beta)$ of the independent variables are equal to zero $(0)$, there is no relationship between the variables in the relationship, and then the null hypothesis would be accepted that no relationship exists between the independent variables and the dependent variable [50].

\subsubsection{The Pearson Chi-Square Model (CSM)}

The primary data values for triangulation are as shown in the multivariate contingency table (Table 1). To each observed frequency $\left(O_{j}\right)$ there is an expected (or theoretical) frequency $\left(E_{j}\right)$ that is computed subject to some hypothesis according to the rules of probability. The cell frequency occupies each cell of the table and the total frequency in each row and each column is the marginal frequency [52] [54]. The row and column frequencies are called the row and column variables respectively and it is apparent that a bivariate distribution permits exploration of relationships between row and column variables [49]. The CSM the stated clearly as:

$$
\chi^{2}=\sum_{i j} \frac{\left(O_{i j}-E_{i j}\right)^{2}}{E_{i j}}
$$

The expected frequencies are calculated from the formula:

$$
E_{i j}=\frac{R_{i} C_{j}}{N}
$$

\begin{tabular}{|c|c|c|c|c|c|}
\hline \multicolumn{6}{|c|}{$\mathrm{H}_{01}: \mathrm{KBE}$ and Globalization does not create wealth } \\
\hline Ranks & High (7 - 10) & Moderate (4 - 6) & Low $(1-3)$ & Zero (0) & Total \\
\hline MSMEs & 35 & 55 & 35 & 25 & 150 \\
\hline Managers & 30 & 20 & 19 & 31 & 100 \\
\hline Others & 12 & 11 & 11 & 16 & 50 \\
\hline Total & 77 & 86 & 65 & 72 & 300 \\
\hline
\end{tabular}

Table 1. Field survey data from structured questionnaire.

\begin{tabular}{|c|c|c|c|c|c|}
\hline \multicolumn{6}{|c|}{$\mathrm{H}_{02}: \mathrm{KBE}$ and Globalization are not correlates } \\
\hline Ranks & High $(7-10)$ & Moderate (4 - 6) & Low (1 - 3) & Zero (0) & Total \\
\hline MSMEs & 25 & 53 & 51 & 21 & 150 \\
\hline Managers & 33 & 28 & 19 & 20 & 100 \\
\hline Others & 15 & 12 & 13 & 10 & 50 \\
\hline Total & 73 & 93 & 83 & 51 & 300 \\
\hline
\end{tabular}


where $E_{i j}=$ the expected frequency for cell in row $i$, and column $j$

$R_{i}=$ the sum of frequencies in the row $i$

$C_{i}=$ the sum of frequencies in column $j$

$N=$ the sum of the frequencies for all cells.

These conditional restrictions of row cells and column cells determine the degrees of freedom (df) to be ( $r-1)$ $(c-1)$, where $\mathrm{r}$ is the number of rows and $c$ is the number of columns [50]. The decision issue involves comparing the calculated chi square value from the sample data with the minimum (critical) value of the chi square distribution (table values) to see the behavior of the data in the model. If the calculated chi square value is higher than the critical value, taking into account the degrees of freedom (df) and the statistical level of significance (in this case, $\alpha=0.05$ ), the null hypothesis is rejected, otherwise it is accepted [50] [51] [53].

\subsection{Data Presentation}

Primary and Secondary data for meta-analyses are as shown in Table 1 and Table 2. Table 2 contained data sorted from Central Bank of Nigeria (CBN), literacy rates and globalization penetration indexes are from Global Economic Review and Internet penetration index from International Telecommunication Union (ITU) Statistics. The MRM model tested hypotheses $\mathrm{H}_{01}$ and $\mathrm{H}_{02}$ using the secondary data. The primary data in Table 1 contained data from field survey conducted using structured questionnaires. Table 1 data tested hypotheses $\mathrm{H}_{01}$ and $\mathrm{H}_{02}$ for triangulation of MRM results by categorizing the field data into 3 (MSMEs, executives of corporations, and others). The primary data is given a 10 point scores describing the behavior and attitude of respondents about KBE and globalization, and their propensity to create or improve the wealth of nations. Score zero (0) showed respondents that are neutral to the KBE and globalization-these are respondents that could be generalized to belong to anti-globalization school. Scores (1 to 3) depicting low depicts respondents who believe mildly in KBE and globalization propensities for wealth creation. Scores (4 to 6) and (7 to 10) believe moderately and highly respectively in the KBE and globalization wealth creation capabilities. The economy of Nigeria, being the case study of this paper; secondary and primary source data are Nigerian content. The primary data specifically is harvested from Abuja, the nation's capital city. Abuja was chosen because of costs and also been a metropolitan city; it is a reflection of business, technology and learning that depicts those required for KBE and globalization studies. Abuja also is the fastest growing city in Africa and ranked among the 20 fastest growing cities in the world and has presence of many corporations with global positioning.

Table 2. Secondary data from CBN statistical bulletin (2010), GER (2014) and ITU (2014).

\begin{tabular}{ccccccccc}
\hline year & $\begin{array}{c}\text { GDP }(\mathrm{W}) \\
\text { Naira }(000)\end{array}$ & $\begin{array}{c}\text { SME Loans }\left(\mathrm{X}_{1}\right) \\
\text { Naira }(000)\end{array}$ & $\begin{array}{c}\text { ME Loans }\left(\mathrm{X}_{2}\right) \\
\text { Naira }(000)\end{array}$ & $\begin{array}{c}\text { Lit.rate } \\
\left(\mathrm{X}_{3}\right) \%\end{array}$ & $\begin{array}{c}\text { GloIE } \\
\left(\mathrm{X}_{4}\right) \%\end{array}$ & $\begin{array}{c}\text { GloIP } \\
\left(\mathrm{X}_{5}\right) \%\end{array}$ & $\begin{array}{c}\text { GloIS } \\
\left(\mathrm{X}_{6}\right) \%\end{array}$ & $\begin{array}{c}\text { Int. } \\
\mathrm{P}\left(\mathrm{X}_{7}\right) \%\end{array}$ \\
\hline 2000 & $4,582,127.29$ & $44,542.30$ & 3666.60 & 54.94 & 60.36 & 83.78 & 16.99 & 0.06 \\
2001 & $4,725,086.00$ & $52,428.40$ & 1314.00 & 54.88 & 60.27 & 84.04 & 15.85 & 0.09 \\
2002 & $6,912,381.25$ & $82,368.40$ & 4310.90 & 54.83 & 62.65 & 84.97 & 15.03 & 0.32 \\
2003 & $8,487,031.57$ & $90,176.50$ & 9954.80 & 54.77 & 63.6 & 87.54 & 16.23 & 0.56 \\
2004 & $11,411,066.91$ & $54,981.20$ & $11,353.80$ & 54.03 & 62.45 & 88.9 & 15.41 & 1.29 \\
2005 & $14,572,239.12$ & $50,672.60$ & $28,504.80$ & 53.29 & 57.87 & 88.07 & 18.06 & 3.55 \\
2006 & $18,564,594.73$ & $25,713.70$ & $16,450.20$ & 52.56 & 61.02 & 89.21 & 19.14 & 5.55 \\
2007 & $20,657,325.00$ & $41,100.40$ & $22,850.20$ & 51.82 & 58.21 & 88.86 & 20.99 & 6.77 \\
2008 & $24,296,329.29$ & $13,512.20$ & $42,753.06$ & 51.08 & 60.11 & 88.9 & 23.55 & 15.86 \\
2009 & $24,794,238.66$ & $63,300.70$ & $58,215.66$ & 56.21 & 62.52 & 89.23 & 24.27 & 20.00 \\
2010 & $29,108,020.00$ & $60,424.70$ & $52,867.50$ & 61.34 & 68.58 & 89.78 & 24.99 & 24.00 \\
2011 & $55,827,900.00$ & $60,298.45$ & $52,853.56$ & 61.34 & 66.23 & 90.14 & 25.19 & 28.43 \\
2012 & $66,644,900.00$ & $60,172.21$ & $52,839.63$ & 61.34 & 66.81 & 90.64 & 31.19 & 32.80 \\
2013 & $83,622,400.00$ & $60,045.96$ & $52,825.69$ & 61.34 & 67.36 & 90.95 & 34.27 & 38.00 \\
Sum & $\mathbf{3 7 4 , 2 0 5 , 6 3 9 . 9 2}$ & $\mathbf{7 5 9 , 7 3 7 . 3 2}$ & $\mathbf{4 1 0 , 7 6 0 . 4 0}$ & NA & NA & NA & NA & NA \\
\hline
\end{tabular}




\section{Analyses, Results and Discussions}

\subsection{Introduction}

The secondary data values went through unit conversion in order to attain common units. The GDP, and SME loans and ME loans variables were converted to percentages and the GDP total was used as a common denominator since both variables are constituents of GDP from accounting (shown in Table 3). The MRM analysis from IBM SPSS 21 software output snap shots are as shown in Tables 4-7.

\subsection{Results Presentation}

The results output showed correlations in Table 4, significance (1-taied) and $\mathrm{N}=14$ as follows:

[SMEs MEs Lit.rate Glo.IE Glo.IP Glo.IS Int.P] =[0.036 0.78 0.75 0.69 0.75 0.94 0.94].

The highest correlation values being 0.94 for Internet penetration and social globalization with political and economic globalizations scores are 0.75 and 0.69 respectively. Micro entrepreneurship and literacy level correlates with scores of 0.78 and 0.75 respectively with small and medium entrepreneurship correlating with scores of 0.036 . All these values are significant $(P<0.05)$. The results output also showed none zero $(0)$ correlation indicating that there is correlation among the predictor variables from the MRM based on the available data in appendix A. This implied that for all cases (i.e. predictors and dependent variable, and among predictors themselves), $r \neq 0$ in other words $(-1 \leq r \leq 1)$. The beta values are also

$\left[\beta_{0} \beta_{1} \beta_{2} \beta_{3} \beta_{4} \beta_{5} \beta_{6} \beta_{7}\right]=[-33.04195 .40-1162.100 .175-1.0141 .09-0.461 .13]$, and are nonzero values as shown from the results output. The variability of predictors are also well accounted for by this MRM as the $R^{2}$ is $0.994(99.4 \%)$ with a zero $(0)$ F change, which is very significant $(P=0.05)$. The Adjusted $R^{2}$ value of 0.987 only indicates a $0.7 \%$ variation which is negligible to cause any spurious effects to model and prediction significance $(P<0.05)$. The F- ratio is also 145.06 and significant $(P<0.05)$, indicating that the MRM used did not predict outside its requirement, implying that the model accurately fits the data. The t-statistics values the contribution of each predictor to the model as the smaller the sig. values, the larger values of t. these values indicates that the predictors contributes significantly in prediction $(P<0.05)$. Lastly, the unstandardized beta (B)

Table 3. Data conversion of Table 1 into percentage scale.

\begin{tabular}{ccccccccc}
\hline Year & GDP $(\mathrm{W})$ \% & SME Loans $\left(\mathrm{X}_{1}\right) \%$ & $\mathrm{ME}$ Loans $\left(\mathrm{X}_{2}\right)$ \% & Lit.rate $\left(\mathrm{X}_{3}\right)$ \% & GloIE $\left(\mathrm{X}_{4}\right) \%$ GloIP $\left(\mathrm{X}_{5}\right) \%$ & GloIS $\left(\mathrm{X}_{6}\right) \%$ & Int.P $\left(\mathrm{X}_{7}\right) \%$ \\
\hline 2000 & 0.120 & 0.012 & 0.001 & 54.94 & 60.36 & 83.78 & 16.99 & 0.06 \\
2001 & 1.260 & 0.014 & 0.0004 & 54.88 & 60.27 & 84.04 & 15.85 & 0.09 \\
2002 & 1.850 & 0.022 & 0.0012 & 54.83 & 62.65 & 84.97 & 15.03 & 0.32 \\
2003 & 2.280 & 0.024 & 0.0027 & 54.77 & 63.6 & 87.54 & 16.23 & 0.56 \\
2004 & 3.050 & 0.015 & 0.0031 & 54.03 & 62.45 & 88.9 & 15.41 & 1.29 \\
2005 & 3.890 & 0.014 & 0.0076 & 53.29 & 57.87 & 88.07 & 18.06 & 3.55 \\
2006 & 4.970 & 0.006 & 0.0045 & 52.56 & 61.02 & 89.21 & 19.14 & 5.55 \\
2007 & 5.530 & 0.011 & 0.0061 & 51.82 & 58.21 & 88.86 & 20.99 & 6.77 \\
2008 & 6.510 & 0.004 & 0.0114 & 51.08 & 60.11 & 88.9 & 23.55 & 15.86 \\
2009 & 6.530 & 0.017 & 0.0156 & 56.21 & 62.52 & 89.23 & 24.27 & 20.00 \\
2010 & 7.790 & 0.016 & 0.0141 & 61.34 & 68.58 & 89.78 & 24.99 & 24.00 \\
2011 & 15.930 & 0.016 & 0.0141 & 61.34 & 66.23 & 90.14 & 25.19 & 28.43 \\
2012 & 17.840 & 0.016 & 0.0141 & 61.34 & 66.81 & 90.64 & 31.19 & 32.80 \\
2013 & 22.450 & 0.016 & 0.0141 & 61.34 & 67.36 & 90.95 & 34.27 & 38.00 \\
Sum & $\mathbf{1 0 0 . 0 0 0}$ & $\mathbf{0 . 2 0 3}$ & $\mathbf{0 . 1 1 0 0}$ & NA & NA & NA & NA & NA \\
\hline
\end{tabular}


Table 4. Pearson correlations of predictors and dependent variable (GDP).

\begin{tabular}{|c|c|c|c|c|c|c|}
\hline \multicolumn{7}{|c|}{ Correlations } \\
\hline & & GDP & SMELoans & MELoans & Lit.rate & Glo.IE \\
\hline \multirow{8}{*}{ Pearson Correlation } & GDP & 1.000 & 0.036 & 0.775 & 0.752 & 0.686 \\
\hline & SMELoans & 0.036 & 1.000 & -0.065 & 0.430 & 0.433 \\
\hline & MELoans & 0.775 & -0.065 & 1.000 & 0.620 & 0.578 \\
\hline & Lit.rate & 0.752 & 0.430 & 0.620 & 1.000 & 0.912 \\
\hline & Glo.IE & 0.686 & 0.433 & 0.578 & 0.912 & 1.000 \\
\hline & Glo.IP & 0.754 & -0.122 & 0.811 & 0.437 & 0.510 \\
\hline & Glo.IS & 0.938 & -0.082 & 0.870 & 0.698 & 0.642 \\
\hline & Int.P & 0.944 & 0.004 & 0.912 & 0.792 & 0.745 \\
\hline \multirow{8}{*}{ Sig. (1-tailed) } & GDP & & 0.452 & 0.001 & 0.001 & 0.003 \\
\hline & SMELoans & 0.452 & . & 0.413 & 0.062 & 0.061 \\
\hline & MELoans & 0.001 & 0.413 & . & 0.009 & 0.015 \\
\hline & Lit.rate & 0.001 & 0.062 & 0.009 & . & 0.000 \\
\hline & Glo.IE & 0.003 & 0.061 & 0.015 & 0.000 & . \\
\hline & Glo.IP & 0.001 & 0.339 & 0.000 & 0.059 & 0.031 \\
\hline & Glo.IS & 0.000 & 0.390 & 0.000 & 0.003 & 0.007 \\
\hline & Int.P & 0.000 & 0.494 & 0.000 & 0.000 & 0.001 \\
\hline \multirow{8}{*}{$\mathrm{N}$} & GDP & 14 & 14 & 14 & 14 & 14 \\
\hline & SMELoans & 14 & 14 & 14 & 14 & 14 \\
\hline & MELoans & 14 & 14 & 14 & 14 & 14 \\
\hline & Lit.rate & 14 & 14 & 14 & 14 & 14 \\
\hline & Glo.IE & 14 & 14 & 14 & 14 & 14 \\
\hline & Glo.IP & 14 & 14 & 14 & 14 & 14 \\
\hline & Glo.IS & 14 & 14 & 14 & 14 & 14 \\
\hline & Int.P & 14 & 14 & 14 & 14 & 14 \\
\hline
\end{tabular}

\begin{tabular}{|c|c|c|c|c|}
\hline \multicolumn{5}{|c|}{ Correlations } \\
\hline & & Glo.IP & Glo.IS & Int.P \\
\hline \multirow{8}{*}{ Pearson Correlation } & GDP & 0.754 & 0.938 & 0.944 \\
\hline & SMELoans & -0.122 & -0.082 & 0.004 \\
\hline & MELoans & 0.811 & 0.870 & 0.912 \\
\hline & Lit.rate & 0.437 & 0.698 & 0.792 \\
\hline & Glo.IE & 0.510 & 0.642 & 0.745 \\
\hline & Glo.IP & 1.000 & 0.749 & 0.763 \\
\hline & Glo.IS & 0.749 & 1.000 & 0.973 \\
\hline & Int.P & 0.763 & 0.973 & 1.000 \\
\hline
\end{tabular}




\begin{tabular}{|c|c|c|c|c|}
\hline \multicolumn{5}{|l|}{ Continued } \\
\hline \multirow{8}{*}{ Sig. (1-tailed) } & GDP & 0.001 & 0.000 & 0.000 \\
\hline & SMELoans & 0.339 & 0.390 & 0.494 \\
\hline & MELoans & 0.000 & 0.000 & 0.000 \\
\hline & Lit.rate & 0.059 & 0.003 & 0.000 \\
\hline & Glo.IE & 0.031 & 0.007 & 0.001 \\
\hline & Glo.IP & . & 0.001 & 0.001 \\
\hline & Glo.IS & 0.001 & . & 0.000 \\
\hline & Int.P & 0.001 & 0.000 & . \\
\hline \multirow{8}{*}{$\mathrm{N}$} & GDP & 14 & 14 & 14 \\
\hline & SMELoans & 14 & 14 & 14 \\
\hline & MELoans & 14 & 14 & 14 \\
\hline & Lit.rate & 14 & 14 & 14 \\
\hline & Glo.IE & 14 & 14 & 14 \\
\hline & Glo.IP & 14 & 14 & 14 \\
\hline & Glo.IS & 14 & 14 & 14 \\
\hline & Int.P & 14 & 14 & 14 \\
\hline
\end{tabular}

Table 5. Standardized and unstandardized coefficients with t statistics.

\begin{tabular}{|c|c|c|c|c|c|c|}
\hline \multicolumn{7}{|c|}{ Coefficients $^{\mathrm{a}}$} \\
\hline & \multirow{2}{*}{ Model } & \multicolumn{2}{|c|}{ Unstandardized Coefficients } & \multirow{2}{*}{$\begin{array}{c}\text { Standardized Coefficients } \\
\text { Beta }\end{array}$} & \multirow{2}{*}{$\mathrm{t}$} & \multirow{2}{*}{ Sig. } \\
\hline & & B & Std. Error & & & \\
\hline \multirow{8}{*}{1} & (Constant) & -33.304 & 20.364 & & -1.635 & 0.153 \\
\hline & SMELoans & 195.397 & 59.259 & 0.152 & 3.297 & 0.016 \\
\hline & MELoans & -1162.104 & 128.267 & -0.996 & -9.060 & 0.000 \\
\hline & Lit. rate & 0.175 & 0.200 & 0.097 & 0.874 & 0.416 \\
\hline & Glo.IE & -1.014 & 0.184 & -0.510 & -5.510 & 0.002 \\
\hline & Glo.IP & 1.090 & 0.179 & 0.376 & 6.080 & 0.001 \\
\hline & Glo.IS & -.462 & 0.222 & -0.410 & -2.086 & 0.082 \\
\hline & Int.P & 1.131 & 0.160 & 2.267 & 7.076 & 0.000 \\
\hline
\end{tabular}

\begin{tabular}{|c|c|c|c|}
\hline \multicolumn{4}{|c|}{ Coefficients $^{\mathrm{a}}$} \\
\hline & \multirow{2}{*}{ Model } & \multicolumn{2}{|c|}{ 95.0\% Confidence Interval for B } \\
\hline & & Lower Bound & Upper Bound \\
\hline \multirow{8}{*}{1} & (Constant) & -83.132 & 16.525 \\
\hline & SMELoans & 50.396 & 340.399 \\
\hline & MELoans & -1475.963 & -848.245 \\
\hline & Lit.rate & -.315 & 0.665 \\
\hline & Glo.IE & -1.464 & -0.563 \\
\hline & Glo.IP & 0.651 & 1.529 \\
\hline & Glo.IS & -1.004 & 0.080 \\
\hline & Int.P & 0.740 & 1.522 \\
\hline
\end{tabular}

${ }^{\mathrm{a} D e p e n d e n t ~ V a r i a b l e: ~ G D P . ~}$ 
Table 6. Model summary showing combined spearman moment coefficients.

\begin{tabular}{|c|c|c|c|c|c|c|}
\hline \multicolumn{7}{|c|}{ Model Summary ${ }^{\mathbf{b}}$} \\
\hline \multirow{2}{*}{ Model } & \multirow{2}{*}{$\mathrm{R}$} & \multirow{2}{*}{ R Square } & \multirow{2}{*}{ Adjusted R Square } & \multirow{2}{*}{ Std. Error of the Estimate } & \multicolumn{2}{|c|}{ Change Statistics } \\
\hline & & & & & R Square Change & F Change \\
\hline 1 & $0.997^{\mathrm{a}}$ & 0.994 & 0.987 & 0.7633481 & 0.994 & 145.602 \\
\hline \multicolumn{7}{|c|}{ Model Summary ${ }^{\mathbf{b}}$} \\
\hline \multirow{2}{*}{ Model } & \multicolumn{6}{|c|}{ Change Statistics } \\
\hline & & df1 & & df2 & Sig. F Ch & \\
\hline 1 & & $7^{\mathrm{a}}$ & & 6 & 0.000 & \\
\hline
\end{tabular}

Predictors: (Constant), Int.P, SMELoans, Glo.IP, Glo.IE, MELoans, Lit.rate, Glo.IS; ${ }^{\mathrm{b}}$ Dependent Variable: GDP.

Table 7. ANOVA values.

\begin{tabular}{|c|c|c|c|c|c|c|}
\hline \multicolumn{7}{|c|}{ ANOVA $^{a}$} \\
\hline & Model & Sum of Squares & df & Mean Square & $\mathrm{F}$ & Sig. \\
\hline \multirow{3}{*}{1} & Regression & 593.895 & 7 & 84.842 & 145.602 & $0.000^{\mathrm{b}}$ \\
\hline & Residual & 3.496 & 6 & 0.583 & & \\
\hline & Total & 597.392 & 13 & & & \\
\hline
\end{tabular}

${ }^{\mathrm{a}}$ Dependent Variable: GDP; ${ }^{\mathrm{b} P r e d i c t o r s: ~(C o n s t a n t), ~ I n t . P, ~ S M E L o a n s, ~ G l o . I P, ~ G l o . I E, ~ M E L o a n s, ~ L i t . r a t e, ~ G l o . I S . ~}$

Table 8. Chi square results output for hypothesis 1.

\begin{tabular}{|c|c|c|c|c|c|}
\hline \multicolumn{6}{|c|}{ Ranks * Category Crosstabulation } \\
\hline \multicolumn{6}{|c|}{ Count } \\
\hline & & \multicolumn{3}{|c|}{ Category } & \multirow{2}{*}{ Tota } \\
\hline & & Exacutives & MSMEs & Others & \\
\hline \multirow{4}{*}{ Ranks } & High & 30 & 35 & 12 & 77 \\
\hline & Low & 19 & 35 & 11 & 65 \\
\hline & Moderate & 20 & 55 & 11 & 86 \\
\hline & Zero & 31 & 25 & 16 & 72 \\
\hline \multicolumn{2}{|c|}{ Total } & 100 & 150 & 50 & 300 \\
\hline
\end{tabular}

\begin{tabular}{|ccccc}
\hline & \multicolumn{5}{c}{ Chi-Square Tests } \\
& Value & df & Asymp. Sig. (2-sided) & Exact Sig. (2-sided) \\
\hline Pearson Chi-Square & $15.107^{\mathrm{a}}$ & 6 & .019 & .019 \\
Likelihood Ratio & 15.303 & 6 & .018 & .020 \\
Fisher's Exact Test & 15.142 & & & .018 \\
N of Valid Cases & 300 & & & \\
\hline
\end{tabular}

a 0 cells $(0.0 \%)$ have expected count less than 5 . The minimum expected count is 10.83 . 
Table 9. Chi square Results for Hypothesis 2.

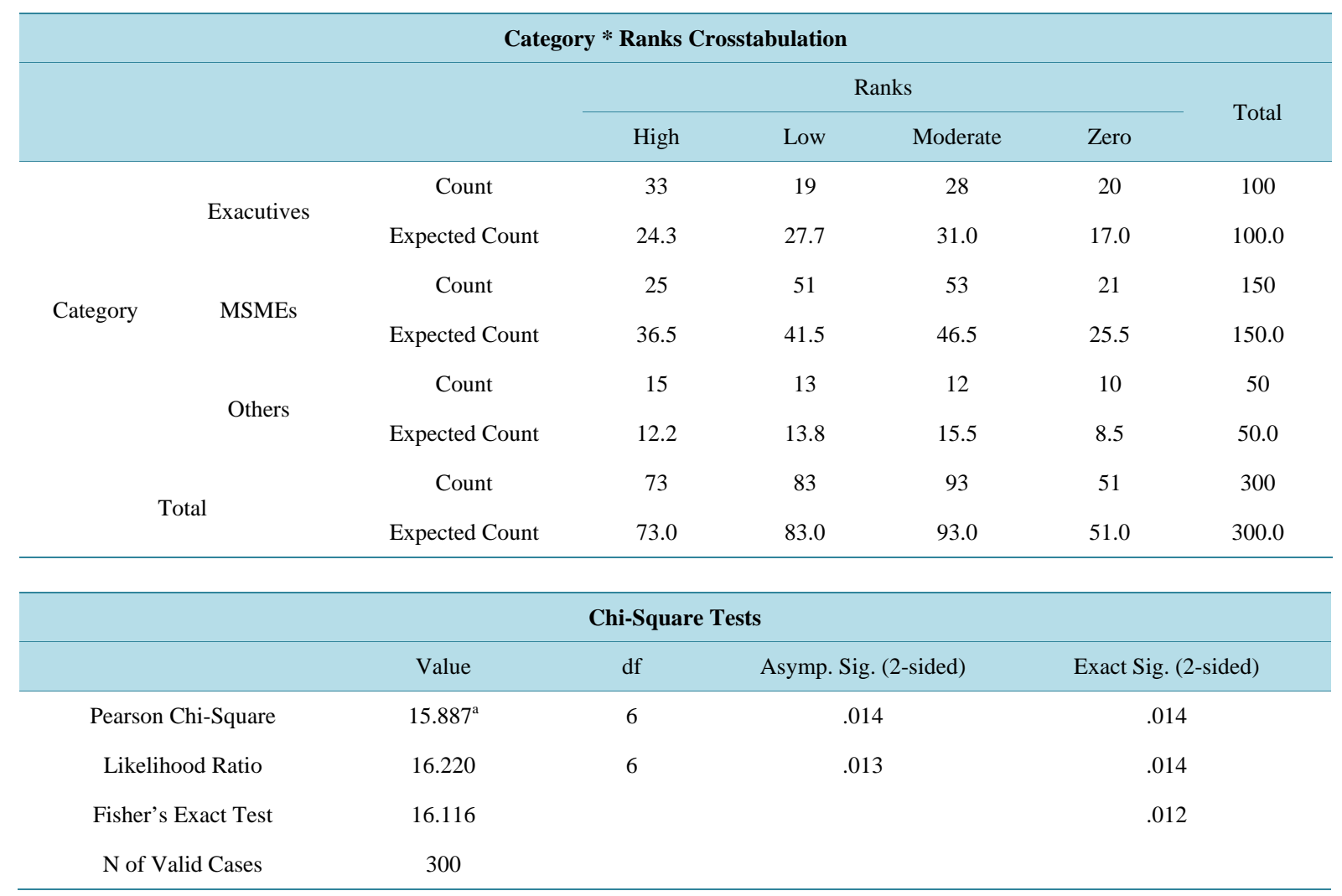

a. 0 cells $(0.0 \%)$ have expected count less than 5 . The minimum expected count is 8.50 .

shows the extent of the contribution of each predictor to the model. Positive values of B indicates positive relationship, while negative values of B indicates negative (inverse) relationship and defines what degree of effect the predictors have on the outcome (prediction). Based on the results output of B values as shown in Table 5, the outcome model now becomes:

$$
\begin{aligned}
\text { Wealth Creation }(\mathrm{GDP})= & \text { 196.397SMEs + 0.175Lit.rate + 1.09Glo.IP + 1.131Int.P } \\
& -1162.104 \mathrm{MEs}-1.014 \mathrm{Glo} . \mathrm{IE}-0.462 \mathrm{Glo} . \mathrm{IS}-33.304 .
\end{aligned}
$$

Thus, the decision rule for hypothesis $\mathrm{H} 01$ is that since $r \neq 0$ (i.e. $-1 \leq r \leq 1$ ); reject $\mathrm{H}_{01}$ indicating that all the predictors acting as KBE and globalization proxy creates the wealth of nations. Hypothesis $\mathrm{H}_{02}$ is also rejected as the predictors of the outcome in the MRM model are very significant with F-ratio of $145.06(P<0.05)$. The determinants have none zero values of correlations ( $r$ ) and significantly correlate together without multicollinearity; as $r>0.9$ values are not substantial in the correlation mix [51]. Also, the critical values of Spearman Correlation Coefficient $(R)$ is 0.997 which is higher than 0.886 at $\mathrm{df} 6$ (real) and 0.786 at df 7 (adjusted) table values at $\alpha=0.05$ for two-tailed test.

The KBE and globalization component variables are positively correlated as the results from the output as presented; [SMEs MEs Lit.rate Glo.IE Glo.IP Glo.IS Int.P] $=\left[\begin{array}{ll}0.036 & 0.780 .750 .690 .750 .940 .94]\end{array}\right.$ and the beta values $\left[\beta_{0} \beta_{1} \beta_{2} \beta_{3} \beta_{4} \beta_{5} \beta_{6} \beta_{7}\right]=[-33.04195 .40-1162.100 .175-1.0141 .09-0.461 .13]$, are nonzero and $\mathrm{t}-$

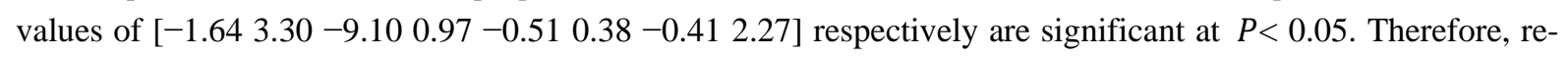
ject both $\mathrm{H}_{01}$ and $\mathrm{H}_{02}$ becauseKBE and globalization are correlates and also relate mutually exclusive to create wealth of nations.

\subsection{Results Triangulation}

Triangulation to parallel using different methods and/or models to achieve the same purpose, with a view to 
providing corroborating evidence, and also "tap different domains of knowing," to encourage or allow expression of different facets of knowledge or experience uses the CSM as shown in the results output in Table 8 and Table 9.

\subsection{1. $\mathrm{H}_{01}$ : KBE and Globalization Does Not Create Wealth}

The Cronbach Alpha for this survey data is valid and reliable at 0.857 which is satisfactory as 0.7 Alpha is required in social science. The Chi square calculated from the data in Table 1 is 15.11 (Table 8) at degrees of freedom (df) of 6 and statistical significance level $(\propto<0.5)$, whilst the appropriate minimum (critical) value in chi square distribution is 12.59 (the calculated value is higher than the critical value). The decision rule is that; the null hypothesis $\left(\mathrm{H}_{01}\right)$ is rejected, indicating that there is significant relationship among the variables. Thus, this analysis shows that KBE and globalization relates to creation of the wealth of nations.

\subsection{2. $\mathrm{H}_{02}$ : KBE and Globalization Are Not Correlates for Wealth Creation}

The reliability Alpha for this field data in Figure 1 is 0.82 and is satisfactory. The chi square calculated is 15.89 (Table 9), whilst the critical Chi square value from tables is 12.59 at $\mathrm{df}$ of 6 and significance level $(\alpha=0.05)$. The decision rule is; reject the null hypothesis $\left(\mathrm{H}_{02}\right)$, indicating a significant relationship existing between the variables and they indeed correlate together for the wealth of nations.

\subsection{Results Discussions}

The results from the MRM and triangulation CSM, a pragmatist positioning, produced are quite convincing for the hypotheses tested. The MRM model produced a nonzero value for correlation coefficients and unstandardized beta (B) values for of all independent variables in the model. Whilst all correlation coefficients are positive, the beta (B) values are mixed (some are negative and others are negative). The combined spearman coefficient $(R)$, the combined coefficient of determination $\left(R^{2}\right)$, and the combined $\mathrm{F}$ values of $0.997,0.994$ and 145.602 were found at a chance $P<0.001$. The $\mathrm{F}$ change is also significant with a value of 0 at a chance of $P<$ 0.001 . Since these values of $R$ and $R^{2}$ are closer to 1 , the explanatory power of the model is close to perfection. That means the data values of the independent variables are explained almost perfectly by the model.

These results both proved that KBE and globalization are correlates for the wealth of nations as they proved hypothesis $\mathrm{H}_{01}$ and $\mathrm{H}_{02}$ respectively. This happened because the results showed that all data of independent variables are 99.4\% explained by the model with low multicollinearity, positive correlation coefficients and beta values of independent variables are not equal to zero. The combined $F$ value is significant with 145.602 and with 0 value of $\mathrm{F}$ change which is unlikely to happen by chance $(P<0.001)$, meaning the model significantly improved the prediction of outcome variables. In the climes of results triangulation, the pragmatist analytic, the primary data obtained (Table 2) also agrees with the secondary data through CSM analysis that there is a relationship between KBE and globalization with the wealth of nations. The $4 \times 3$ bivariate contingency table data for the hypotheses agreed to this effect. While table 7 results showed that KBE and globalization are mutually exclusive to create the wealth of nations, they also relate as correlates (Table 8), because their chi square values are 15.11 and 15.89 higher than their respective critical chi square values of 12.59 at a statistical level of significance of $\alpha=0.05$ respectively. Thus, within the limits of the secondary and primary data obtained for this inquiry, it has been found scientifically that KBE and globalization are mutually exclusive in wealth creation, and correlates for the wealth of nations in a developing economy of Nigeria, and by extension, for the wealth of nations of developed economies. The works of this paper as discussed afore therefore vehemently supports and extends "KBE and globalization wealth creation theory" as attempted by seminal works [15] [27] [42] [43] [46] in the theoretical reviews.

\section{Conclusion and Recommendations}

\subsection{Conclusion}

This paper made an original contribution to knowledge by first attempting a concept definition of knowledge based entrepreneurship (KBE) as "a phenomenon driven mainly by the climes of information-knowledge philosophy which is characterized by high value innovation and creativity, deploying technology, information and communication technology (ICT) epistemologies for product and services giving commercial or market value.” 
Thus, it fulfils the third objective of this paper. Globalization on the other hand, in this paper is being adopted conceptually from Baylis and Smith as, "that on-going trend whereby the world in many respect and at a generally accelerating rate become one relatively borderless sphere. Territorial spaces remain significant to be sure, but the geography of the world politics is now no longer reducible to territoriality" [7]. Second, these two phenomena are considered as independent variables and indeed correlates for the wealth of nations due to their invaluable capacities and as revealed by the foregoing theoretical review and meta-analysis. The proxy of KBE as defined in the review is these variables that engender innovation, creativity, entrepreneurial culture and orientation with science and technology to underpin optima value creation. These include measurable inputs such as MSME performance and literacy rates at a given time period in the economy. Globalization on the other hand is a multifaceted, multidisciplinary and complex phenomenon that is proxy on economic, political and social globalization indexes, and internet penetration at a given time period in the same economy.

Lastly, this paper analysed relevant primary and secondary data in Nigeria and found that, "KBE and globalization phenomena are mutually exclusive and collectively exhaustive for the wealth of nations and are inextricably and intrinsically invaluable correlates in wealth creation. In other words, train the entrepreneurs through life-long learning provided by structured education and unstructured experiential learning to acquire tacit knowledge, and to transform the tacit knowledge into explicit knowledge within the ethos of relevant science and technology, innovation and creativity, and ambidextrous entrepreneurial culture. Also, encourage and increase globalization philosophy through same education, technological acquisition, increased socioeconomic and political integration, and Internet penetration in that economy. Then, the continuous marginal streams of benefit flows that will accumulate the sum of wealth become the dominant wealth creation character and charter in that economy. This is the third original contribution to the body of knowledge by this paper confirming objective 3.

\subsection{Recommendations}

The answer to question 1 has been given and objectives 1 fulfilled by these results from the two tested hypotheses. But how can these are achieved in Nigeria? The answer is to consider policy issues in sub-question 2 and objective 2: to develop a policy framework for adopting and adapting the KBE and globalization phenomena for value optimization in Nigeria. Thus recommended policy issues by this paper will involve first, a revisit to the Nigerian Content Bill for reengineering and improved implementation at all levels in order to boost indigenous participation in product extraction, development and export trade. High innovative products required for export markets would require high-tech and high innovative products and services that KBE philosophy acquire should have sway in the economy. Second, the Small and Medium Entrepreneurship Development (SMEDAN) Act should also be reengineered to perform its mandate by realistically becoming a "one-stop-shop" for entrepreneurship development in Nigeria. This would create more participation for the MSMEs in all sectors and levels of the economy in product development and service delivery, enable increased access to finance and "doing business" in Nigeria. Integrative learning from technology-led and online education (E-learning) and entrepreneurship education (both structured and unstructured types) should be encouraged and empowered. Technology improvement and increased e-commerce participation vide creation of networks with firms of global positioning and with globalization content should be part of entrepreneurship in Nigeria. Third, the leadership and policy governance in Nigeria should stop been clueless but chart policy directions with implementation monitoring and evaluation, and with feedback in order to realize the objective of fostering KBE and globalization with high business activity level in the economy. This will involve public governance that will remove institutional disconnects, procedural bottle-necks, favoritisms and partialities, and operational wastages by enthroning best business practices, lean management and meritocracies to boost empowerment and participation in all sectors of the economy in Nigeria. Fourth, striving for an entrepreneurial and globalized economy in Nigeria where entrepreneurship venturing will be well, continuous and flourishing. This will involve a total turn around and mental revolution of top policy makers and implementers; to stop playing lips services with policy, but use its instrumentality for explosive KBE and globalization for wealth creation in Nigeria.

Finally, this paper is silent about the weight and direction of correlation and relationship of KBE and globalization with wealth because they are both outside its object, though very much invaluable, thus further research in that direction is recommended. Due to factors of multiple causation, multicollinearity and spurious relationships that are usually associated with multiple regression models, a more competent meta-analytic approach to 
prove or/and possibly extend this work is also recommended. Multi causation is the position that a phenomenon can have several causes, multicollinearity is where two independent variables significantly overlaps, and spurious relationship is that relationship between two variables that is caused by a third variable [49]. Lastly, the paper recommended effective policies by Nigeria in the direction of KBE and globalization so as to explore and exploit the capital underlying these phenomena.

\section{References}

[1] Kanellos, N. (2013) Exploring the Characteristics of Knowledge-Based Entrepreneurship in Greek High-Technology Sector. Economics and Management of Innovation, Technology and Organizations. DRUID Academy Conference for Doctoral Students, Aalborg, 16-18 January 2013. http://druid8.sit.aau.dk/acc_papers/ji6bdjxuk1yi79hl5r2asugg4es0.pdf

[2] Bishop, K. (2006) Knowledge Based Entrepreneurship in the Czech Republic and Hungary: Results from 4 Case Studies. Knowledge, Entrepreneurship, Innovation, Networks and Systems STREP Project, Universitá Bocconi, Milan.

[3] Witt, U. and Zellner, C. (2005) Knowledge-Based Entrepreneurship: The Organizational Side of Technology Commercialization. CEMI-REPORT-2005-002.

http://infoscience.epfl.ch/record/52229/files/WP\%20Knowledgebased\%20Entrepreneurship.pdf

[4] Landstrom, H. (2006) Entrepreneurship Research and the Knowledge Economy. World Conference on Intellectual Capital, Paris, 29-30 June 2006. http://info.worldbank.org/etools/docs/library/235926/s8_p2.pdf

[5] Heeboll, J. (2007) Knowledge Based Entrepreneurship Textbook, DTU 42705. Copenhagen University of Science.

[6] Millenium Report (2000) We the Peoples: Globalization and Governance. The Role of United Nations in the $21^{\text {st }}$ Century by Kofi Annan, Secretary General of the United Nations.

[7] Baylis, J. and Smith, S. (2001) The Globalization of World Politics, an Introduction to International Relations. 2nd Edition, Oxford University Press, London.

[8] Adesina, S.O. (2012) The Negative Impact of Globalization on Nigeria. International Journal of Humanities and Social Science, 2. www.ijhssnet.com

[9] Audretsch, D.B. and Sanders, M. (2007) Globalization and the Rise of Entrepreneurial Economy. Jena Economics Research Papers 003_2007. The Jena Economic Research Papers is a Joint Publication of the Friedrich-SchillerUniversity and the Max Planck Institute of Economics, Jena, Germany. http://zs.thulb.uni-jena.de/servlets/MCRFileNodeServlet/jportal_derivate_00019217/wp_2007_003.pdf

[10] Audretsch, D.B., Grilo, I. and Turik, A.R. (2012) Globalization, Entrepreneurship and Region. http://www.entrepreneurship-sme.eu/pdf-ez/H201201.pdf

[11] WEF (2011) Global Entrepreneurship and the Successful Growth Strategies of Early-Stage Companies. A World Economic Forum Report in Collaboration with Stanford University, Graduate School of Business, SPRIE and STVP. www.weforum.org/usa.

[12] Kelley, D.J., Bosma, N., Amorós, J.E. and Global Entrepreneurship Research Association (GERA) (2010) Global Entrepreneurship Monitor (GEM). 2010 Global Report. http://entreprenorskapsforum.se/wp-content/uploads/2011/02/GEM-2010-Global-Report.pdf

[13] Natsheh, A.A., Gbadegeshin, A.S., Rimpilainen, A. and Mainela, T. (2013) Technology Based Entrepreneurship: Measurement Technology Perspective. Interdisciplinary Journal of Research in Business, 2, 26-42.

[14] Dahlstrand, O. (2007) Entrepreneurship and Development. FSF (Swedish Foundation for Small Business Research).

[15] Mohammad, A.C., Mohammad, A.F., Mohammad, K.B. and Iqra, A. (2011) Globalization and Its Impacts on the World Economic Development. International Journal of Business and Social Science, 2, 291-297.

[16] Chinnammai, S. (2002) Effects of Globalization on Education and Culture. ICDE International Conference, New Delhi, 19-23 November 2005, 16.

[17] CodurasMartínez, A., Levie, J., Kelley, D.J., Sæmundsson, R.J., Schøtt, T. and the Global Entrepreneurship Research Association (GERA) (2012) A Global Perspective on Entrepreneurship Education and Training. Global Entrepreneurship Monitor Special Report. http://www.gemconsortium.org/

[18] Daft, L.R. (2010) New Era of Management. International Edition, Thompson South-Western, Cengage Learning, Mason.

[19] Gareth, R.J. and George, J.M. (2007) Contemporary Management. Fifth Edition, McGraw-Hill, Boston.

[20] Scarborough, S.N. (2011) Essentials of Entrepreneurship and Small Business Management. 6th Edition, Pearson Education Inc., Upper Saddle River. 
[21] Kelley, D.J., Ali, A., Brush, C., Corbett, A.C., Lyons, T., Majbouri, M., Rogoff, E.G., Babson College and Baruch College (2013) GEM USA Report. National Entrepreneurial Assessment for the United States of America. Global Entrepreneurship Monitor. http://www.gemconsortium.org/

[22] GEM OECD Report (2013) Entrepreneurship in Ireland, the Annual Report for Ireland. Global Entrepreneurship Monitor. http://www.gemconsortium.org/

[23] GEF Report (2014) World GDP. Global Economic Forum.

[24] NBS Report (2012) NBS Briefing on Nigeria Poverty Profile 2010. Press Briefing by the Statistician-General of the Federation/Chief Executive Officer, National Bureau of Statistics, Dr. Yemi Kale Held at the Conference Room, 5th Floor, NBS Headquarters, Central Business District, Abuja.

[25] MSME Survey (2012) Survey Report on the Micro, Small and Medium Enterprises in Nigeria. A Prelimi NaryReport, 2010 National MSME Collaborative Survey. A Collaboration between National Bureau for Statistics (NBS) and the Small and Medium Enterprises Agency of Nigeria (SMEDAN). http://www.smedan.gov.ng/doc

[26] Gujarati, D. and Sangeetha, N. (2007) Basic Econometrics. Fourth Edition, Tata McGraw-Hill, New Delhi.

[27] Shahabadi, M.M.M. and Etamad, R.A. (2013) Effect of Globalization on Entrepreneurship: An Economical Point of View. International Journal of Management and Humanity Sciences, 2, 1033-1038. http://www.ijmhsjournal.com

[28] Chinn, P.L. and Kramer, M.K. (1999) Theory and Nursing: A Systematic Approach. Fifth Edition, Mosby, St Louis.

[29] Khan, J.A. (2008) Research Methodology. A.P.H. Publishing Corporation, New Delhi.

[30] Nickels, G.W., McHugh, M.J. and McHugh, M.S. (2006) Understanding Business. 10th Edition, McGraw-Hill, Boston.

[31] Longenecker, J.G., Moore, C.W. and Petty, J.W. (1997) Small Business Management: An Entrepreneurial Emphasis. South-Western Publishing, Cincinati.

[32] Laudon, C.K. and Laudon, P.J. (2007) Management Information Systems, Managing the Digital Firm. Tenth Edition, Pearson Education Inc., Upper Saddle River.

[33] Drucker, P.F. (1998) The Age of Discontinuity. Reprinted Edition, Butterworth-Heinemann, Oxford.

[34] Carton, R. (2003) Entrepreneur and Entrepreneurship, Operational Definition of Their Role in Society. An Article Published at the Terry College of Business, University of Georgia, Athens.

[35] Hisrich, D.R., Peters, M.P. and Dean, A.S. (2008) Entrepreneurship. 7th Edition, McGraw-Hill International Edition, Boston.

[36] Drucker, P. (1993) Innovation and Entrepreneurship: Practice and Principles. Harper Collins Publishers, Inc., New York.

[37] Wolk, M.A. (2007) Social Entrepreneurship and Government: A New Breed of Entrepreneurs Developing Solutions to Social Problems. The Small Business Economy: A Report to the President, 2007. The Small Business Administration, Office of Advocacy. A Root CAUSE Report 2007.

[38] Ayatse, F.A. (2013) Driving Entrepreneurship Education in Nigeria: Issues and Challenges. International Journal of Business and Management Review, 1, 88-90.

[39] Kelley, D.J., Singer, S., Herrington, M. and the Global Entrepreneurship Research Association (GERA) (2011) GEM Report. 2011 Global Report. The Global Entrepreneurship Monitor. http://www.gemconsortium.org/

[40] Thang, N.N., Quang, T. and Son, H.N. (2013) Knowledge Creation and Green Entrepreneurship: A Study of Two Vietnamese Green Firms. Asian Academy of Management Journal, 18, 129-151.

[41] Beirjerse, R.P. (2000) Knowledge Management in Small and Medium-Sized Companies: Knowledge Management for Entrepreneurs. Journal of Knowledge Management, 4, 162-179. http://dx.doi.org/10.1108/13673270010372297

[42] Georgiou, M.N. (2010) Globalization and Entrepreneurship on Economic Growth: An Empirical Analysis (1999-2006). http://ssrn.com/abstract=1724611

[43] Othman, N., Othman, H. and Ismail, R. (2012) Impact of Globalization on Entrepreneurship Education and Entrepreneurial Skills in Higher Education Institutions. 2012 2nd International Conference on Economics, Trade and Development (IPEDR), Vol. 36, IACSIT Press, Singapore.

[44] Kim, K.J. and Bonk, C. (2006) The Future of Online Teaching and Learning in Higher Education: The Survey Says... EDUCAUSE Quarterly Magazine, 29, 22-30.

[45] Shear, L., Toyama, A. and Lasseter, A. (2012) Understanding the Implications of Online Learning for Educational Productivity. U.S. Department of Education, Office of Educational Technology, Centre for Technology in Learning, SRI International. http://www.ed.gov/technology

[46] Akuhwa, P.T. and Akorga, B.S. (2010) Network-Based Strategies and Operational Excellence of Small and Medium Entre- 
preneurship Businesses in Nigeria. National Conference on "Managing the Challenges of Global Financial Crisis in Developing Economies”, Nassarawa State University, Keffi, 9-11 March 2010, 1-16.

[47] Johnson, B.R. and Onwuegbuzie, J.A. (2004) Mixed Methods Research: A Research Paradigm Whose Time Has Come. Educational Researcher, 33, 14-26. http://dx.doi.org/10.3102/0013189X033007014

[48] Bazeley, P. (2002) Issues in Mixing Qualitative and Quantitative Approaches to Research. Research Support P/L, Bowral, Australia. 1st International Conference-Qualitative Research in Marketing and Management, University of Economics and Business Administration, Vienna, 10 April 2002, 1-11.

[49] Roscoe, J.T. (1975) Fundamental Research Statistics for the Behavioral Science, International Series in Decision Process, 2nd Edition, Holt, Rinehart and Winston, Inc., New York.

[50] Meier, K.J., Brudney, J.L. and Bohte, J. (2009) Applied Statistics for Public and Nonprofit Administration. International Student Edition, 7th Edition, Thomson Wadsworth, Belmont.

[51] Field, A. (2009) Discovering Statistics Using SPSS. 3rd Edition, SAGE Publications Ltd., London.

[52] Walpole, R.E. and Myers, R.H. (1978) Probability and Statistics for Engineers and Scientists. Collier Macmillan International Editions, 2nd Edition, Macmillan Publishing Company, Inc., New York.

[53] Howell, D.C. (2007) Statistical Methods for Psychology. 6th Edition, Thomson Wadsworth, Belmont.

[54] Spiegel, R.M. and Stephens, L.J. (2007) Statistics, Schaum’s Outline Series. 4th Edition, McGraw-Hill, New York. 